\title{
Characteristics of Pathological Fluor Albus on Outpatient in Permata Serdang Mother and Child Hospital Year 2019
}

\author{
Hans Eldith Monintja ${ }^{1}$, Adinta Anandani ${ }^{2}$ \\ 1) Medical Study Program, Faculty of Medicine and Health, Universitas Muhammadiyah Jakarta \\ 2) Department of Microbiology and Parasitology, Medical Study Program Faculty of Medicine and Health, Universitas \\ Muhammadiyah Jakarta \\ *Corresponding author: hanseldithmonintja@gmail.com
}

\begin{abstract}
Background: Based on Indonesia Ministry of Health in 2010, about $75 \%$ of woman ever had a vaginal discharge at least once in a lifetime and $45 \%$ of woman had vaginal discharge twice or more. The most common risk factor that causing pathological fluor albus is genital organ hygiene. Purposes: The objective of this study is to determine the characteristics of pathological fluor albus on outpatient in RSIA Permata Serdang in 2019. Methods: This was an observational study based on medical record samples in 74 patients with pathological fluor albus between January 2019 and December 2019. Results: From 74 patients with pathological fluor albus, the highest age range occurred 25-29 years age category $(24.3 \%)$, with the most marital status was married $(97.3 \%)$, and the most dominant occupation was housewife $(51.4 \%)$ and mostly living in Serang (52.7\%). Clinical manifestations were itching and odor (28.4\%), itching $(27 \%)$, itching with pain and odor $(14.9 \%)$, odor $(10.8 \%)$. The secret color is clear $(86.5 \%)$ followed by white-coloured secret $(13.5 \%)$. Physical examination have been done with speculum examination (77\%). Management provided for the patients are metronidazole $(86.5 \%)$ and fluconazole (13.5\%). Conclusion: Pathological fluor albus at RSIA Permata Serdang occurs often aged 25-29 years in a married woman with the common characteristic complaint was itching with odor.
\end{abstract}

Keywords: Fluor Albus; Pathological Fluor Albus; Clinical Characteristic; Bacterial Vaginosis.

\section{INTRODUCTION}

Fluor albus or known as vaginal discharge is the name of the symptom of a complaint that is most often found in women, namely discharge from the genital organs but not blood and can be a normal (physiological) condition or as a sign of a disease (pathological). Normal fluor albus usually appears clear to whitish, odorless and causes no complaints. Pathological fluor albus is usually yellowish / greenish / grayish in color, smells fishy / foul, the amount of secretions is generally large and causes complaints such as itching (pruritus), redness (erythema), edema, burning sensation in the genital area, pain during coitus (dyspareunia) or pain during micturition (dysuria) (1).

Bacterial vaginosis is the most common condition causing pathological fluor albus, followed by candidiasis. Nearly $30 \%$ of women of reproductive age (14 - 49 years) in the United States have experienced bacterial vaginosis (2). 
Candidiasis vulvovaginitis has a global prevalence of 3871 per 100,000 women and $50 \%$ of women affected by candidiasis experience recurrent infections (3).

Indonesia is a tropical country has a high moist level making it easier to trigger excessive sweating. The importance of maintaining the health and hygiene of the reproductive organs will have an impact on the occurrence of fluor albus in a woman. Knowledge of how to care for the genital organs is needed properly because it is a major factor in maintaining the health and cleanliness of the female reproductive organs. Lack of knowledge in maintaining the health and cleanliness of female reproductive organs can create a risk for pathological fluor albus due to lack of maintaining the cleanliness of intimate organs (4).

Fluor albus can occur in women of all ages from young age, reproductive age to old age and does not recognize the socioeconomic level, although this case is more common in women with low educational and socioeconomic levels. Therefore, we conducted research on fluor albus to find its prevalence and characteristics (5).

This research was conducted at Permata Serdang Mom and Child Hospital, located in Serang. This hospital is a type C hospital.

\section{METHODS}

This type of research is a descriptive study with an observation approach. The samples were all patients suffering from pathological fluor albus in 2019 using total sampling, in this study we only used 74 medical records of patients with fluor albus pathological met the inclusion criteria of the study. All medical records used in this study were obtained from the outpatient medical records section.
Preparations for the study until the study done were conducted from February to July 2020. Samples would not be included if the patient experiences physiological fluor albus in pregnant women patients.

Variables obtained from age, marital status, occupation, education, domicile, clinical symptoms, gynecological examination, laboratory studies, treatments. After data collection, the data will be processed using the Statistical Package for the Social Sciences (SPSS) program version 25 .

The research ethics permit was obtained from the Health Research Ethics Committee of the Faculty of Medicine and Health, Muhammadiyah University, Jakarta. The ethics approval number is 008 / PE / KE / FKK-UMJ / IV / 2020.

\section{RESULT}

The results of 74 patients with inclusion and exclusion criteria. Patients treated at Permata Serdang Mother and Child Hospital in 2019.

The results are shown in the following sections. Table 1 shows the demographic characteristics. It is evident from the table that majority of women belonged to the age-group of $25-29$ years (24.3\%), followed by the age-group 30-34 years $(23 \%)$. Around 19 percent belonged to the age group 20-24 years, and around 16 percent to $40-44$ years. Further, about 97 percent woman were married and among these some were in either work as housewife $(51.4 \%)$, or had taken up private employee jobs (29.7\%). A total of 62.2 percent woman were college-educated, followed by 31.1 percent had attended high school and 2 percent had attended junior high school and 1 percent elementary school. The highest pathological fluor albus 
sufferer was live in Serang with a percentage of $52.7 \%$.

It can be seen that in this study based on the clinical picture of pathological fluor albus patients, 21 people (28.4\%) had complaints of itching and odor, 20 patients complain itching (27\%), 14 people (18.9\%) pain and odor, with all three complaints were 11 people (14.9\%) and only complaint odor many as 8 people $(10.8 \%)$. The color of the secretions of pathological fluor albus patients in this hospital were found that 64 people with a clear secret were obtained with a percentage of $86.5 \%$ and white colour as many as 10 people with a percentage of $13.5 \%$. Based on Speculum Examination of pathological fluor albus patients, 57 people were found done this examination with a percentage of $77 \%$. Based on the management of pathological fluor albus patients, 64 people with metronidazole were obtained with a percentage of $86.5 \%$ and 10 people with fluconazole with a percentage of $13.5 \%$.

Table 1.Showing Demographic Characteristics

\begin{tabular}{lcc}
\hline Variable & $\begin{array}{c}\text { Frequency } \\
(\mathbf{n})\end{array}$ & $\begin{array}{c}\text { Percent } \\
(\boldsymbol{\%})\end{array}$ \\
\hline Age & 0 & \\
$15-19$ & 14 & 18.9 \\
$20-24$ & 18 & 24.3 \\
$25-29$ & 17 & 23 \\
$30-34$ & 9 & 12.2 \\
$35-39$ & 12 & 16.2 \\
$40-44$ & 2 & 2.7 \\
$45-49$ & 2 & 2.7 \\
$>50$ & & \\
Marital Status & 72 & 97.3 \\
Married & 2 & 2.7 \\
Not Married & & \\
Occupation & 38 & 51.4 \\
Housewife & 22 & 29.7 \\
Private Employee & 22 & 10.8 \\
Civil Servant & 8 & 6.8 \\
Entrepeneur & 5 &
\end{tabular}

\begin{tabular}{lcc}
\hline $\begin{array}{c}\text { Non-Civil Servant } \\
\text { Education }\end{array}$ & 1 & 1.4 \\
College & 46 & 62.2 \\
High School & 23 & 31.1 \\
Junior High & 2 & 2.7 \\
No data & 2 & 2.7 \\
Elementary & 1 & 1.4
\end{tabular}

\section{Domicile}

Serang

39

52.7

Cilegon

34

Outside Banten

1.4

Clinical Symptoms

$\begin{array}{lcc}\text { Ithing+Odor } & 21 & 28.4 \\ \text { Itchy } & 20 & 27 \\ \text { Pain+Odor } & 14 & 18.9 \\ \text { ching+Pain+Odor } & 11 & 14.9 \\ \text { Odor } & 8 & 10.8 \\ \text { Pain } & 0 & 0 \\ \text { Itching+Pain } & 0 & 0\end{array}$

Vaginal Secret

Color

$\begin{array}{lll}\text { Clear } & 64 & 86.5 \\ \text { White } & 10 & 13.5\end{array}$

Speculum

Examination

$\begin{array}{lll}\text { Yes } & 57 & 77 \\ \text { No } & 17 & 23\end{array}$

Management

\begin{tabular}{ccc} 
Metronidazole & 64 & 86.5 \\
Fluconazole & 10 & 13.5 \\
Total & 74 & 100.0 \\
\hline
\end{tabular}

\section{DISCUSSION}

Based on the data obtained from the patients medical records, the age group that experienced the most complaints of pathological fluor albus in this study were 18 patients $(24.3 \%)$.

A good age to get pregnant for women of reproductive age is between $20-35$ years. Of course, in this age range women have been doing a lot of activities such as working and also actively engaging in sexual activity with partner which increases the risk of being infected if personal 
hygiene is not good. The attitudes and knowledge by women of reproductive age is one of the important factors that can influence respondents to improve their health status (6).

From 74 patients in this study, most $(97.3 \%)$ patients who experienced pathological fluor albus were married. This is consistent with the theory that married women have an increased risk of experiencing pathological fluor albus, possibly due to sexual activity. Physiologically discharge of fluid excess of the genital organs of women can be found at the time of ovulation, and when he gets sexual stimulation before or while having $\operatorname{sex}(6)$.

Based on a study conducted on patients with pathological fluor albus from the total population in this study, 21 people (28.4\%) had complaints of itching and odor, 20 patients complain itching (27\%), 14 people $(18.9 \%)$ pain and odor, with all three complaints were 11 people $(14.9 \%)$ and only complaint odor many as 8 people $(10.8 \%)$. Fluor albus pathological with majority vaginal secret color is clear as many as 64 people $(86.5 \%)$ and white color as many as 10 people (13.5\%).

Characteristics of patients with complaints of fluor albus pathological generally have complaints that red colored, excessive secret, smells, itchy or burningfeel, and also often causing injuries due to scratching in the area of the mouth, vagina (7).

The gynecological examination carried out in this study was that the bimanual examination was not done on 74 people $(100 \%)$. And speculum examinations were carried out on 57 people (77\%).

A general gynecological examination should be performed to detect possible chronic and other diseases associated with fluor albus. Examinations that specifically must be carried out are genital examinations which include inspection and palpation of the external genitalia; inspeculo examination to see the vagina and cervix; bimanual examination (8).

Laboratory tests in this study it was found that all the patients as many as 74 people (100\%) do not conduct the tests, such as routine blood tests, saline wet mount examination, examination of $\mathrm{KOH}$ 10-20\% and Gram stain. This laboratories test is important to determine the organism causing the complaint.

$\mathrm{KOH} 10 \%$ examination procedure needs to be done to make a diagnosis of candidiasis. The vaginal secretions were taken and put on a glass slide and then dripped with $\mathrm{KOH} 10 \%$ so that it could be identified whether there were budding yeast cells . If need to be cultured, can by using media commonly used is Sabouraud Dextrose order (SDA) to see the growth of colonies that look gray and creamy and moist (9). To diagnose bacterial vaginosis can be through clinical criteria or through a laboratory, namely microscopic examination by assessing the morphology of the bacteria (10).

From 74 patients who had complaints of fluor albus pathological, therapy given most common is metronidazole $(86.5 \%)$ and flukonazole (13.5\%).

In a study conducted at the National Central General Hospital Dr. Cipto Mangunkusumo in 2008 regarding the pattern of fluor albus treatment at the hospital, it was found that generally metronidazole is a drug that is often used to treat bacterial vaginosis and for candidiasis, the most commonly used drug is fluconazole (11). 


\section{CONCLUSION}

Based on the results of the study, the highest age category were 25-29 years $(24.3 \%)$ with the most common marital status was married (97.3\%). The most common clinical symptoms are itchy and smelly (28.4\%) with clear secretion color (86.5\%). Physical examination was done with percentage of $77 \%$ and no laboratories tests conducted to the patient. The treatment of patients with pathological fluor albus was mostly metronidazole (86.5\%).

\section{ACKNOWLEDGMENT}

The authors would like to thank the Permata Serdang Mother and Child Hospital for given permission to take a 74 samples and make this process done well. We would also like to thank to Muhammadiyah University of Jakarta and all friends who have helped and supported this research.

\section{CONFLICT OF INTEREST}

Authors state have no conflict of interest, and no affiliation or connection to or with any entity or organization, which may raise a question of bias in discussion and conclusion of the manuscript.

\section{REFERENCE}

1. Meena V, Bansal CL. Study to Evaluate Targeted Management and Syndromic Management in Women Presenting with Abnormal Vaginal Discharge. J Obstet Gynaecol India. 2016 Oct;66(Suppl 1):534-40.

2. Wilson MMG. Sexually transmitted diseases. Clin Geriatr Med. 2003;19(3):637-55.

3. Gonçalves B, Ferreira C, Alves CT, Henriques M, Azeredo J, Silva S. Vulvovaginal candidiasis: Epidemiology, microbiology and risk factors. Crit Rev Microbiol.
2016 Nov;42(6):905-27.

4. Indrawati K. Upaya Meningkatkan Pengetahuan Tentang Kesehatan Organ Reproduksi Siswi Kelas VIII SMPN 10 Surabaya Melalui Metode Tutor Sebaya (Efforts to Increase Knowledge of the Health of Reproductive Organs for Class VIII Students of SMPN 10 Surabaya Through the Peer Method). EJournal Dinas Pendidik Kota Surabaya. 2011;5:1-11.

5. Kaur J, Kapoor A. Perceptions and Knowledge about Leukorrhea in a Slum Dwelling South Asian Community. J Fam Reprod Heal [Internet]. 2014 Mar;8(1):45-52. Available from: https://pubmed.ncbi.nlm.nih.gov/24 971133

6. Murtiastutik D, Lumintang $\mathrm{H}$, Barakbah J, Sunarko M. Textbook of Sexually Transmitted Infections (Buku Ajar Infeksi Menular Seksual). Surabaya: Airlangga University Press; 2008.

7. Schorge. Infeksi saluran genitalia bawah. In: Obstetrics and Gynaecology at a Glance. Jakarta: Erlangga; 2008. p. 20-1.

8. Ralph C. Diseases of the vulva and vagina (Penyakit pada vulva dan vagina). In: Benson and Pernoll's Handbook of Obstetric \& Gynecology. Jakarta: ECG; 2009. p. 503-4.

9. Brooks G, Carroll K, Butel J, Morse S, Mietzner T. Medical Microbiology (Mikrobiologi Kedokteran). Jakarta: Salemba Medika; 2004.

10. Chaijareenont K, Sirimai K, Boriboonhirunsarn D, Kiriwat O. Accuracy of Nugent's score and each 
Amsel's criteria in the diagnosis of bacterial vaginosis. J Med Assoc Thai. 2004 Nov;87(11):1270-4.

11. Rusdi NK, Trisna Y, Soemiati A. Pola Pengobatan Fluor Albus di Rumah Sakit Umum Pusat Nasional Dr Cipto Mangunkusumo serta Faktor - Faktor yang Mempengaruhinya (Analisis Data Rekam Medik Tahun 2006-2007) (Pattern of Treatment of Fluor Albus in the National General Hospital Dr. Cipto Mangunkusumo Hospital as well as the Factors that Influence it (Analysis of Medical Record Data of the Year 2006-2007). Pharm Sci Res.

2008;5(2):91-100. 